\title{
Studying Althaea officinalis L. by an introduction experiment in the Kuzbass Botanical Garden (KuzBS)
}

\author{
Oxana Vronskaya*, and Oxana Tsandekova \\ Federal Research Center of Coal and Coal Chemistry SB RAS, 650065 Kemerovo, Russia
}

\begin{abstract}
Althaea officinalis L. was studied in the Kuzbass Botanical Garden. It's a perennial herbaceous plant, that is included in the Red Book of the Kemerovo Region with the status 2 - declining. During the first year of life, the following ontogenetic stages are recognized under introduction conditions: seedling, juvenile, immature, virginile, and young generative. A semi-rosette orthotropic monocarpic shoot, branching in a sylleptic way, and a caudex emerge in the first year. In pregenerative plants, there is an increase in ascorbic acid but a decrease in the activity of phenolic compounds and malonic dialdehyde; in generative plants, there is an inverse link.
\end{abstract}

The genus Althaea has 25 species. Althaea. officinalis L. is a perennial herbaceous plant with medicinal value $[1,2,3]$. Included in the Red Book of the Kemerovo Region with status 2 - declining [4].

In Kuzbass, natural populations of Althaea. officinalis L. suffer from anthropogenic pressure. Grazing and late haying harm the plants. Uncontrolled collection of underground organs as medicinal raw material leads to a decline in the abundance of Althaea officinalis. To preserve the population, detailed research of Althaea officinalis under introduction conditions is required.

An evaluation of the success of a biological foundation for introduction is required when developing one. An assessment of a species' primary introduction is required in the early phases of introduction [5].

Morphological structure, developmental rhythms, reproductive mechanisms, and ontogeny

A. officinalis has been studied mainly in the European part of Russia [6]. There is no information on the development of this species in Siberia.

The purpose of this work is to investigate the biological characteristics of A. officinalis at various stages of ontogenesis under the conditions of the introduction experiment in the Kuzbass Botanical Garden (KuzBS).

Materials and methods. The work was carried out in 2019-2021 in the Kuzbass Botanical Garden (Kemerovo), located in the northern part of the forest-steppe zone of Western Siberia. The climate of the study area is sharply continental. The average annual air temperature is $0.9^{\circ} \mathrm{C}$. The highest air temperature is in summer $\left(35 \ldots .38^{\circ} \mathrm{C}\right)$, the lowest

* Corresponding author: oksana_vronski@mail.ru 
is in winter $\left(-57^{\circ} \mathrm{C}\right)$. The first spring frosts occur from 28 May to $11 \mathrm{June}$ and the first autumn frosts from 26 August to 14 September. The average annual rainfall is $450 \ldots 500$ $\mathrm{mm}$. The height of the snow cover is between 47 and $72 \mathrm{~cm} .76$

Seeds of Althaea officinalis 1- collected on the territory of KuzBS and seeds of Althaea officinalis 2 received via Index seminum from the University of Tartu Botanical Gardens were used as material for the study.

The concept of a discrete description of ontogenesis was used for researching the stages of A. officinalis ontogenesis under introduction conditions [7,8]. The life form and type of the shoot in the initial stages of ontogenesis is defined by I.G. Serebryakov $[9,10]$. The inflorescence is described by T.V. Kuznetsova et al [11]. Biochemical analysis of the raw material was carried out for ascorbic acid [12], phenolic compounds [13] and malonic dialdehyde [14].

Findings.

During the investigation of A. officinalis ontogeny, no significant changes in phenotype were discovered between individuals of the two groups.

During the first year of life in the Kuzbass Botanical Garden, individuals of A. officinalis go through five ontogenetic stages: seedling, juvenile, immature, virginile, and young generative.

Latent period. The seeds are small, bud-shaped, dark brown, glabrous.

Seedlings. Germination is above ground. The hypocotyl is glabrous, and the seedlings have a primary shoot, two broadly oval, subopposite cotyledonous leaves, and an open apical bud. The main root branches out to 2 nd order. The duration of the ontogenetic stage is $15-20$ days.

Juvenile plants. It forms a primary rosette shoot with ten assimilating pubescent leaves that are circular in shape and have narrow lanceolate pubescent leaf stalks. The main root pulls the hypocotyl into the soil and the cotyledon node is on the soil surface.

The duration of the juvenile stage is on average 15-20 days.

Immature plants. A semi-rosette shoot is formed. The juvenile leaves are succeeded by adult leaves with pubescent bracts at the base. The 1st order lateral roots increase in diameter.

Virginile plants. The rosette leaves progressively die off, revealing a semi-rosette orthotropic monocarpic shoot branching in a sylleptic way.

Young generative plants. The flowering of the marshmallow occurs in the first year of life. The inflorescence is a multi-stemmed dichasia open thyrsus, and the synflorescence is a thyrsus tassel. The above-ground elongated component of the main shoot dies off towards the end of the growing season, while the rosette with regeneration buds is pushed into the soil by contractile activity of the main and lateral roots and becomes perpetual. The caudex arises when the primary and lateral roots drag the rosette part of the shoot into the soil.

At the initial stages of development ( $\mathrm{j}, \mathrm{im}, \mathrm{v}$ ) of A. officinalis, during active plant growth, there was a vigorous formation of ascorbic acid, but a decrease in phenols and malonic dialdehyde levels, which is obviously associated with increased processes of rearrangement of proteins, carbohydrates, fats and with new cell and tissue formation. The maximum ascorbic acid level was found during the generative period, during inflorescence production, especially in A. officinalis $1(40.95 \mathrm{mg} / 100 \mathrm{~g})$. This is due to the maximal development of the assimilative surface of the leaves and the active processes occurring in them at photosynthesis, creation and accumulation of huge amounts of metabolites for transformation into reproductive organs and usage in the energy processes of flowering.

During flower opening, the ascorbic acid content in the test specimen leaves declined to $30.18 \mathrm{mg} / 100 \mathrm{~g}$, which is explained by its transfer into the growing inflorescences together with carbohydrates and other assimilation products. 
The dynamics of phenolic compound accumulation in the studied samples ranged from 0.84 to $2.7 \%$, and malonic dialdehyde from 6.54 to $11.61 \mathrm{nmol} / \mathrm{g}$, with a maximum during flower opening, which is associated with a sharp increase in synthetic processes in the leaves, used for growth and development of reproductive structures. A. officinalis 2 contains 1-1.3 times more phenolic chemicals and malonic dialdehyde than the first sample.

Conclusion. During the first year of life in the Kuzbass Botanical Garden, individuals of A. officinalis go through five ontogenetic stages: seedling, juvenile, immature, virginile, and young generative.

Main developmental stages: formation of a semi-rosette orthotropic monocarpic shoot branching in a sylleptic way; inflorescence - open thyrsus from multilobed dichasia, and synflorescence - thyrsus tassel; dying off by the end of vegetation of above-ground elongated part of the main shoot and pulling rosette part with regenerating buds into the soil; caudex formation.

In pregenerative plants, there is an increase in ascorbic acid but a decrease in the activity of phenolic compounds and malonic dialdehyde; in generative plants, there is an inverse link.

The work was made within the limits of the National task of The Federal Research Center of Coal and Coal Chemistry of Siberian Branch of the Russian Academy of Sciences AAAA-A17- 117041410053-1 (Project № 0352-2016-0002) «Evaluation of a state and protection of floristic variety affected by anthropogenic and technogenic factors in situ и ех situ». On the base of USS Introduction fund KuzBS № USU 508670

\section{References}

1. G. O. Osmanova, Ontogenetic Atlas of Medicinal Plants, IV (Mari State University, Yoshkar-Ola, 2004)

2. Ali Esmail Al-Snafi, International Journal of PharmTech Research, 5(3) (2013)

3. SM Ali Shah, Naveed Akhtar, M. Akram, Pervaiz Akhtar Shah, Tariq Saeed, Khalil Ahmed, H. M. Asif, Journal of Medicinal Plant Research 5 (24) (2011)

4. Red Book of the Kemerovo Region: Rare and Endangered Species of Plants and Fungi (Asia Print, Kemerovo, 2012)

5. A. N. Kupriyanov, Theory and practice of plant introduction (Kemerovo, Irbis, 2013)

6. M. M. Ilyin, Malvae. Flora of the USSR, Vol.15 (M.-L., 1949).

7. T. A. Rabotnov, M. S. Shalyt, Geobotany, Series 3 (Moscow, Academy of Sciences publishing house, 1950)

8. I. G. Serebryakov, Morphology of the Vegetative Organs of Higher Plants (Moscow, Soviet science, 1952)

9. W. Troll, Die Infl oreszenzen (Jena, 1964)

10. I. G. Serebryakov, Ecological Morphology of Plants (Moscow, Higher School, 1962)

11. T. V. Kuznetsova, N. I. Pryakhina, G. P. Yakovlev, Inflorescences. Morphological Classification (Chemical-Pharmaceutical Institute, St. Petersburg, 1992)

12. O. A. Neverova, Biochemistry Workshop for University Students (KemTIPP, Kemerovo, 2005)

13. I. M. Korenskaya, N. P. Ivanovskaya, I. E. Izmalkova, Medicinal plants and medicinal plant raw materials containing anthracene derivatives of simple phenols, lignans, tannins (Voronezh, 2007) 
14. G. F. Nekrasova, I. S. Kiseleva, Ecological Physiology of Plants: Guidelines for Laboratory and Practical Classes (Yekaterinburg, Ural State University, 2008) 